Artikel Penelitian

\title{
Pemberian Terapi Vitamin C pada COVID-19
}

\author{
Mohammad Hasan, Yelvi Levani, Afrita Amalia Laitupa, Nenny Triastuti
}

Program Pendidikan Dokter Universitas Muhammadiyah Surabaya.

Email:mohhsn078@gmail.com

\begin{abstract}
Abstrak
Vitamin C merupakan salah satu nutrisi yang tidak bisa disintesis oleh manusia. Fungsi Vitamin $C$ dalam tubuh sangat banyak, salah satunya sebagai antioksidan dan efek pada sistem imun. Vitamin C terbukti dapat melawan virus karena sebagai imunomodulasi, sehingga dapat meningkatkan produksi interferon dan mengatur sintesis sitokin proinflamasi. Vitamin $\mathrm{C}$ berhasil mencegah dan mengurangi pasien ICU pada ISPA. Vitamin C juga mepercepat kesembuhan pada penyakit flu. Pemberian terapi vitamin $C$ diharapkan membantu dalam menurunkan morbiditas dan mortalitas pada COVID-19. Vitamin C pada tubuh pasien COVID-19 juga menurun, sehingga sangat dibutuhkan terapi vitamin C. Vitamin C dapat sebagai imunosupresan yang akan menghambat cytokin storm pada pasien COVID-19. Vitamin C dalam pasien yang terinfeksi virus dapat menghambat ROS. Pemberian vitamin $\mathrm{C}$ dengan dosis tinggi dapat membantu penyembuhan dalam dengan sepsis. Dokter di China melaporkan 50 pasien COVID-19 dengan pemberian vitamin C berhasil sembuh. Hal ini dapat membuktikan vitamin C dapat dijadikan terapi pada pasien COVID-19. Tujuan pembuatan literature review ini untuk mengatahui efektivitas vitamin C pada pasien COVID-19.
\end{abstract}

Kata kunci: Vitamin C, Terapi, COVID-19

(cc) $\mathrm{Br}$

This work is licensed under a Creative Commons Attribution 3.0 License. 


\section{PENDAHULUAN}

Pada 31 Desember 2019, World Health Organization (WHO) melaporkan kasus pneumonia yang tidak diketahui etiologinya di kota Wuhan, China. Pada tanggal 7 Januari 2020, Coronavirus Disease 2019 (COVID-19) ditemukan dari virus golongan coronavirus yang diidentifikasi dari kasus pneumonia yang tidak diketahui etiologinya tersebut. Sars-CoV-2 adalah virus penyebab COVID-19. COVID-19 juga ditetapkan sebagai Kedaruratan Kesehatan Masyarakat Yang Meresahkan Dunia (KKMMD). Transmisi COVID-19 sama seperti jenis coronavirus yang lainnya, yaitu berasal dari hewan tapi hewan yang menjadi sumber COVID-19 masih belum ditemukan. COVID-19 merupakan virus pandemi yang menyebar ke seluruh dunia. ${ }^{1}$

COVID-19 menyebar dengan cepat ke seluruh dunia. Pada 3 maret 2020 tercatat bahwa 90.870 kasus terkonfirmasi di 72 negara dengan 3.112 kematian dan Case Fatality Rate (CFR 3,4\%), diwaktu yang sama Indonesia masih tercatat 2 kasus. ${ }^{1}$ Tapi pada 4 juni, Indonesia masuk ke urutan 32 secara global dengan jumlah kasus 28.181 dengan 1.721 kematian. Tingkat kematian meningkat pada usia diatas 80 tahun CFR 2,19\%. Pasien dengan riwayat penyakit sebelumnya mempunyai CFR yang tinggi; 13,2\% untuk pasien yang memiliki penyakit kardiovaskuler, 9,2\% untuk pasien diabetes, 8,4\% untuk hipertensi, 8,0\% untuk penyakit pernapasan kronis dan $7,6 \%$ untuk kanker. ${ }^{2}$

Kasus COVID-19 yang parah menyebabkan kematian setiap hari karena kurangnya perawatan antivirus khusus dan tekanan perawatan klinis. ${ }^{3}$
Salah satu penanganan COVID-19 yang paling efektif adalah vaksin karena biaya yang lebih murah dari pada pengobatan, mengurangi morbiditas dan mortalitas tanpa efek panjang. Namun, vaksin untuk COVID19 masih belum ditemukan. ${ }^{4}$

Penelitian untuk pembuatan obat atau vaksin COVID-19 masih dalam tahap pencarian. Vitamin $C$ dikaitkan dengan terapi COVID-19. Vitamin $\mathrm{C}$ juga mempunyai sifat antioksidan yang mampu melindungi sel dan jaringan. ${ }^{5}$ Vitamin $\mathrm{C}$ diketahui memiliki peran pleiotropik dalam sistem kekebalan tubuh, melalui antioksidan dan aktivitas kofaktor enzim. Intake tubuh terhadap vitamin C yang tinggi bisa menurunkan infeksi respirasi. ${ }^{6}$

\section{METODE PENULISAN TINJAUAN LITERATUR}

Metode yang digunakan pada penelitian ini adalah mengumpulkan dan menganalisis artikel penelitian terkait terapi vitamin C pada Penyakit COVID-19. Artikel yang didapatkan melalui pencarian menggunakan electronic database Google Scholar, PubMed, dan Elsevier dengan menggunakan kata kunci Vitamin C, Terapi, dan COVID-19. Tujuan membuat literature ini untuk mengetahui pengaruh pemberian terapi vitamin C pada pasien COVID-19. Seluruh artikel yang dibahas mengenai COVID-19, format full-text, dimana spesifikasinya membahas mengenai terapi vitamin C pada COVID-19.

\section{PEMBAHASAN \\ Virologi COVID-19}

COVID-19 merupakan virus RNA, berukuran 150-160 nm dan bentuknya bulat atau oval. Genom 
COVID-19 mirip dengan SARS-CoV dan MERS-CoV. ${ }^{7,8}$ COVID-19 merupakan genus Betacoronavirus dan subgenus Sarbecovirus. Sekuens COVID-19 mirip dengan coronavirus yang diisolasi pada kalelawar. ${ }^{9}$

Urutan asam amino COVID-19 berbeda dengan coronavirus yang lain terutama pada polyprotein dan Sprotein. S-protein pada COVID-19 memiliki dua subunit, salah satu unit mengikat receptor pada host. ${ }^{8}$ COVID19 mempunyai envelope, pleomorfik atau partikel bulat, nucleoprotein, capsid, matrix, dan S-protein. ${ }^{8}$ Struktural protein utama COVID-19 adalah spike protein (S), membrane protein $(\mathrm{M})$, dan envelopeprotein $(\mathrm{E})$. Sprotein berfungsi atas interaksi reseptor sel inang dan virus. Sedangkan protein $\mathrm{E}$ dan $\mathrm{M}$ berfungsi untuk struktur dan fusi membran. Akan tetapi, protein $\mathrm{N}$ mengikat RNA virus dan memediasi interaksinya dengan protein $\mathrm{S}, \mathrm{E}$, dan $M$ untuk enkapsulasi genom. Beberapa protein yang penting pada replikasi virus yaitu protease (nsp5), papain-like protease (nsp3), dan RNA-dependent RNA polymerase (nsp12, RdRp). ${ }^{10}$

Siklus hidup COVID-19 serupa dengan coronavirus yang lain. Secara umum, siklus hidup COVID-19 dimulai dengan pengikatan virus ke sel target dan berujung pada reproduksi virus. ${ }^{10}$ Pada COVID-19, data invitro mendukung kemungkinan virus mampu masuk ke dalam sel menggunakan reseptor Angiotensin converting enzyme 2 (ACE 2). COVID-19 tidak menggunakan reseptor coronavirus lainnya seperti Aminopeptidase $N$ (APN) dan Dipeptidyl peptidase-4 (DPP-4). ${ }^{9}$ Proses ini dimediasi oleh pengikatan protease membran lain yaitu transmembrane serine protease 2 (TMPRSS2), yang membelah $S$ protein sebagai langkah penting fusi membran.

Perbedaan molekuler yang menjelaskan perbedaan klinis penting antara infeksi COVID-19 dan coronavirus lainnya, seperti latensi yang berkepanjangan dan gejala yang bervariasi. $^{10}$

\section{Patogenesis COVID-19}

Transmisi penularan COVID-19 melalui droplet resiprasi, kontak langsung dan potensial dalam fecaloral. $^{3}$ Glikoprotein yang terdapat di selubung virus COVID-19 akan berikatan dengan reseptor Angiotensinconverting enzyme 2 (ACE 2). ${ }^{8}$ Setelah menembus membran, genom RNA virus memasuki intraseluler. Setelah replikasi, menghasilkan rantai polipeptida masif tunggal, dimana 16 protein konstituen dibelah. Proses ini awalnya dimediasi oleh protease intraseluler, kemudian diperbanyak dengan fungsi protease utama COVID19 dan papain-like proteas. Protein replikasi lain, RNA-dependent $R N A$ polymerase (RdRp) berfungsi untuk replikasi dan amplifikasi genom virus. Protein lebih banyak setelah amplifikasi RNA virus. ${ }^{10}$

Genom RNA yang berada di dalam sel akan dikeluarkan ke sitoplasma selanjutnya virus akan bereplikasi. $^{9}$ Epitel mukosa respirasi atas (rongga hidung dan faring) merupakan tempat virus bereplikasi pertama kali, lalu replikasi selanjutnya di respirasi bawah dan mukosa gastrointestinal. $^{3} \quad$ Glikoprotein yang baru terbentuk akan masuk kedalam retikulum endoplasma. Partikel virus akan tumbuh ke dalam retikulum endoplasma. Pada tahap akhir, komponen virus baru dilepaskan dari vesikel yang mengandung partikel virus 
yang bergabung dengan membran plasma. $^{9}$

Pada tahap ini dapat menimbulkan gejala pada respirasi maupun gejala non-respirasi, infeksi juga bisa dikendalikan sehingga tidak menimbulkan gejala. ACE 2 diekspresikan dalam mukosa hidung, bronkus, paru, jantung, kerongkongan, ginjal, lambung, kandung kemih, ileum, dan organ manusia ini semuanya rentan terhadap COVID-19. ${ }^{3}$

Terdapat dua fase respons imun pada kasus COVID-19, yaitu tahap inkubasi dan non-severe stages. Respons imun adaptif sangat dibutuhkan untuk mencegah perkembangan ke severe stages. Jika respons imun terganggu, virus akan menyebar dan menginfeksi jaringan terutama pada organ yang memiliki receptor ACE-2 yang banyak. Sel-sel yang rusak dapat menginduksi inflamasi pada paru dan menyebabkan peradangan yang dimediasi oleh makrofag dan granulosit proinflamasi. ${ }^{11}$

\section{Acute Respiratory Distress}

Syndrome (ARDS) merupakan kondisi paru yang sangat mengancam jiwa.,12 Masuknya virus menyebabkan migrasi dan aktivasi neutrofil yang berakibat rusaknya dinding alveolar-kapiler. ${ }^{7}$ Cytokine Release Syndrome (CRS) mempengaruhi pasien dalam kondisi parah, karena pada pasien COVID-19 yang parah sering terjadi limfositopenia. Sitokin inflamasi juga (IL-1, TNF) sangat tinggi pada paru pasien COVID19 dan sitokin ini merupakan penginduksi kuat HA-synthase-2 (HAS2) dalam CD31+ endotelium, $E p C A M+$ sel-sel epitel alveolar paru, dan fibroblas. Hyaluronan (HA) memiliki kemampuan untuk menyerap air hingga sehingga menyebabkan kesulitan bernapas. ${ }^{11}$
Klasifikasi Gejala COVID-19

$$
\text { COVID-19 berdasarkan }
$$

beratnya kasus dibedakan menjadi lima. Pertama kasus tanpa gejala yaitu tidak ditemukan gejala pada pasien. Kedua kasus ringan atau tidak berkomplikasi yang ditandai dengan gejala tidak spesifik seperti demam, lemah, batuk, anoreksia, malaise, nyeri otot, sakit tenggorokan, sesak ringan, kongesti hidung dan sakit kepala. Ketiga kasus sedang yaitu disertai dengan pneumonia tanpa gejala pneumonia dan tidak membutuhkan suplementasi oksigen. Keempat kasus berat dengan ditandai gejala pneumonia ditambah satu gejala : frekuensi napas $>30 \mathrm{x} /$ menit, distress pernapasan berat, atau saturasi oksigen $<93 \%$ pada udara kamar atau rasio $\mathrm{PaO} 2 / \mathrm{FiO} 2<300$. Yang terakhir kasus kritis yang ditandai gagal napas, Acute Respiratory Distress Syndrome (ARDS), syok sepsis dan/atau multiple organ failure. $^{12}$

\section{Vitamin C}

Vitamin $\mathrm{C}$ adalah nutrisi penting yang tidak dapat disintesis oleh manusia. Vitamin $\mathrm{C}$ memiliki banyak kontribusi terhadap sistem imun (imun innate dan adaptif). Vitamin C juga berperan sebagai antioksidan yang mampu menyumbangkan elektron, sehingga melindungi biomolekul penting yang rusak oleh oksidan hasil metabolisme tubuh, paparan racun dan polutan. Vitamin $\mathrm{C}$ juga merupakan kofaktor untuk biosentesis, gen pengatur dan enzim dioksigenase. Vitamin ini sudah lama dikenal sebagai kofaktor untuk lisis dan prolyl hidroksilase. Vitamin C meningkatkan colagen, carnitine, catecholamines, amidated peptides dan menurunkan 
hypoxia-inducible factor, dna methylation dan histone methylation. ${ }^{13}$

\section{Farmakologi vitamin C}

Konsentrasi vitamin C dalam plasma dan jaringan dikontrol oleh tiga mekanisme, yaitu absorpsi, transportasi jaringan dan reabsoprsi beserta eksresi ginjal. $^{14}$ Vitamin $\mathrm{C}$ diabsorpsi melalui saluran cerna. Vitamin $\mathrm{C}$ dalam darah sangat mudah dioksidasi menjadi dehidroaskorbat. $^{15} \quad$ Vitamin $\quad \mathrm{C}$ menyumbangkan elektron ke substrat, sementara vitamin $C$ teroksidasi menjadi radikal ascorbyl. Dua molekul radikal bebas ascorbyl dapat terurai menjadi 1 molekul askorbat dan 1 molekul asam dehydroascorbic. ${ }^{16}$ Vitamin C dibawa oleh sodium vitamin C co-transporter (SVCT). ${ }^{17}$ Vitamin C masuk ke mitokondria dalam bentuk dehidroaskorbat. Dehidroaskorbat yang diangkut berkurang di mitokondria. Dehidroaskorbat juga direduksi kembali menjadi askorbat oleh dehidroaskorbat reduktase dan pengurangan glutathione. Askorbat keluar dari mitokondria. Langkah-langkah terakhir sintesis askorbat terjadi di endoplasma retikulum. ${ }^{18}$

Vitamin C secara spontan teroksidasi baik intraseluler dan ekstraseluler menjadi bentuk yang tidak aktif secara biologis. ${ }^{17}$ Distribusi vitamin $C$ keseluruh tubuh sangat baik, dengan kadar tertinggi dalam kelenjar dan terendah dalam otot. ${ }^{15}$ Jaringan spesifik mengkontrol penyerapan vitamin $\mathrm{C}$, distribusi jaringan, dan ekskresi oleh transpor aktif melalui SVCT1 dan SVCT2. ${ }^{16}$ SVCT2 berfungsi sebagai distribusi ke jaringan. Akumulasi vitamin C terjadi melalui transportasi askorbat teroksidasi, asam dehidroaskorbat dan diikuti oleh pengurangan intraselulernya. SVCT1 memediasi penyerapan vitamin C pada ginjal. ${ }^{14}$ Persediaan tubuh sebagian besar di cotex ginjal. ${ }^{19}$ Vitamin C diekskresi melalui urin dalam bentuk utuh dan garam sulfat jika kadar dalam darah melewati ambang rangsang ginjal. ${ }^{15}$ Ekskresi berlangsung sebagai metabolit dehidronya dan sedikit sebagai asam oksalat. ${ }^{19}$

Transporter askorbat sebagian besar berada pada jaringan epitel. Transporter askorbat juga terlibat dalam penyerapan askorbat dan reabsorpsi ginjal, untuk mempertahankan homeostasis seluruh tubuh. ${ }^{18}$ Fungsi enzimatik vitamin C sebagai kofaktor untuk ferrous [Fe (II)] dan dioksigenase dependen 2oxoglutarate dalam sintesis kolagen. Enzim-enzim ini mengkatalisasi hidroksilasi lisin dan residu prolin dalam rantai prokolagen, yang merupakan blok bangunan struktur triple-heliks dari kolagen fungsional yang matang dan fungsional. ${ }^{16}$

Vitamin $\mathrm{C}$ berfungsi sebagai donor elektron untuk berbagai enzim yang mengkatalisis biosintesis karnitin dan norepinefrin, peptida hormone amidation, dan metabolisme tirosin. Hidroksilasi yang dimediasi askorbat dari hipoksia inducible factor 1a (HIF1a) mengatur transkripsi beberapa gen yang mengkode protein yang terlibat dalam homeostasis besi, angiogenesis, dan proliferasi sel. Vitamin C memodulasi vasorelaksasi dengan meningkatkan sintesis NO atau bioavailabilitas. $^{16} \quad$ Vitamin $\quad \mathrm{C}$ terkonsentrasi dalam leukosit, limfosit, dan makrofag. Vitamin $\mathrm{C}$ juga meningkatkan chemotaxis, aktivitas fagositik neutrofil dan kematian oksidatif. Proliferasi limfosit juga dipercepat oleh vitamin C. ${ }^{20}$ Vitamin C juga mendaur ulang tetrahydrobiopterin 
dari bentuknya yang teroksidasi, sehingga mempertahankan aktivitas enzim, Tetrahydrobiopterin adalah kofaktor untuk aktivitas Endothelial NO synthase (eNOS). ${ }^{16}$ Vitamin C juga bertindak sebagai kofaktor untuk sejumlah biosintesis dan gen pengatur gen dan enzim dioksigenase, menunjukkan efek modulasi kekebalan. ${ }^{21}$

$\begin{array}{lcr}\text { Vitamin } & \text { C } & \begin{array}{r}\text { merupakan } \\ \text { imunomodulator }\end{array} \\ \begin{array}{l}\text { yang } \\ \text { menstimulasi }\end{array} & \begin{array}{r}\text { dapingi } \\ \text { meningkatkan }\end{array} & \begin{array}{r}\text { neutrofil, } \\ \text { fagositosis, }\end{array}\end{array}$
pembentukan oksidan, dan membunuh mikroba. Disaat yang sama, vitamin C melindungi jaringan host dari kerusakan berlebihan dengan meningkatkan apoptosis neutrofil dan pembersihan oleh makrofag, dan mengurangi nekrosis neutrofil. ${ }^{13}$

Peran lain vitamin C dalam fungsi vaskular termasuk memodulasi penghalang sel endotel dan mengatur aktivitas NADPH oksidase (NOX) yang terlibat dalam respons gen inflamasi. Vitamin $C$ juga dapat meregenerasi vitamin $E$ (a-tokoferol) dari bentuk teroksidasi (a-tokoferheril radikal), memungkinkan vitamin $\mathrm{C}$ untuk secara tidak langsung menghambat peroksidasi lipid. ${ }^{16}$ Vitamin $\mathrm{C}$ adalah antioksidan yang kuat, sehingga dapat membersihkan radikal bebas dan mengembalikan antioksidan seluler lainnya. ${ }^{20}$

Selain diperoleh dari suplemen, vitamin $C$ juga bisa diperoleh dari buah dan sayur. ${ }^{22}$ Dosis yang tepat buat orang dewasa adalah 2 gram/hari. Suplementasi oral dengan $500 \mathrm{mg} /$ hari dibutuhkan pada kasus yang lebih ringan, tetapi terapi parenteral mungkin diperlukan pada kasus yang berat. Asupan vitmain $\mathrm{C}$ yang tinggi bisa menyebabkan gagal ginjal. ${ }^{16}$ Risiko dosis tinggi bisa menyebabkan hemolisis dan batu ginjal. ${ }^{14}$

Angka kecukupan gizi vitamin $C$ ialah $35 \mathrm{mg}$ untuk bayi dan meningkat $60 \mathrm{mg}$ pada dewasa. Kebutuhan akan vitamin C meningkat $300-500 \%$ pada penyakit infeksi. Efek samping penggunaan dosis tinggi bisa menyebabkan batu ginjal oksalat dan diare. ${ }^{19}$ Diare disebabkan oleh iritasi pada mukosa usus yang menyebabkan peningkatan peristaltik, sedangkan batu ginjal disebabkan karena metabolisme dan ekskresi dalam bentuk oksalat. ${ }^{15}$ Dosis diatas $500 \mathrm{mg}$ bisa merusak selDNA karena adenosin dirusak oleh dehidroaskorbat yang bekerja sebaga prooksidan. ${ }^{19}$

\section{DISKUSI}

Pada COVID-19 kerusakan sel terjadi karena peningkatan oxidative stress dan mengakibatkan kegagalan organ. ARDS merupakan penyebab utama oxidative stress pada pasien COVID-19, karena mengakibatkan radikal bebas dan stikon meningkat. Vaksin dan antivirus yang tepat masih belum ditemukan, maka pemberian obat suportif dan antioksidan memiliki peran penting dalam kasus COVID-19. Pemberian intravena vitamin $C$ sangat bagus dan diterapkan pada kasus COVID-19. ${ }^{20}$

Kerusakan paru hal yang harus diwaspadai dalam pemulihan pasien COVID-19, karena membutuhkan respons imun yang baik, maka dibutuhkan terapi untuk meningkatkan respons imun. ${ }^{11}$ Vitamin $\mathrm{C}$ memiliki aktivitas klinis dalam melawan virus. Vitamin C sebagai imunomodulasi pada pasien dengan infeksi virus dan meningkatkan produksi interferon dan mengatur sintesis sitokin proinflamasi. ${ }^{20,23}$ Pemberian vitamin C 
dosis tinggi bertindak sebagai prooksidan untuk sel kekebalan tubuh, sekaligus sebagai antioksidan untuk sel epitel paru. ${ }^{17}$

Vitamin $C$ dapat menghambat nuclear factor kappa-B (NFkB) dan berperan penting dalam kekebalan tubuh termasuk regulasi chemokines, cytokines, adhesion molecules, mediator inflamasi dan menghambat apoptosis. Vitamin C dapat mempengaruhi respon Granulocyte macrophage colony stimulating factor (GM-CSF) yang berfungsi sebagai pertahanan dan mengkontrol respons inflamasi. Vitamin $\mathrm{C}$ dosis tinggi dapat mengatur proliferasi dari sel $\mathrm{T}$, sel $\mathrm{B}$ dan natural killer (NK) yang dapat membantu menghambat perkembangan cytokines storm. ${ }^{24}$

Vitamin $\mathrm{C}$ dalam tubuh menurun dalam kasus COVID-19 yang disebabkan oleh sitokin inflamasi dan peningkatan konsumsi vitamin $\mathrm{C}$ pada sel somatik. ${ }^{9}$ Dalam meta-analisis dengan 29 uji coba terkontrol dengan 11.306 peserta yang diberikan asupan vitamin C 1 gram/hari tidak dapat mencegah Infeksi Saluran Nafas Atas (ISPA). Namun, dari hasil uji coba yang sama, Vitamin $C$ dapat memperpendek dan mengurangi ISPA. Pada frekuensi dan gejala ISPA yang ringan, maka vitamin $\mathrm{C}$ memberikan dampak yang sedikit dan dosis profilaksis vitamin $C$ tidak berguna jika keadaan normal. ${ }^{25}$

Pasien COVID-19 yang diberikan vitamin $\mathrm{C}$ lebih baik dari pada pasien yang tidak diberikan vitamin C. ${ }^{24}$ Dalam metaanalisis dengan delapan uji coba yang memberikan vitamin $\mathrm{C}$ terhadap infeksi flu biasa dapat mengurangi dan menghilangkan gejala. Dalam metaanalisis lain dari delapan uji coba pada 3135 anak, diberikan suplementasi vitamin $\mathrm{C}$ tidak mencegah infeksi penyakit saluran pernapasan atas, tetapi mengurangi durasi infeksi hingga 1,6 hari. $^{21}$

Kasus Intensive Care Unit (ICU) dalam pasien COVID-19 sangat tinggi. Metaanalisis dalam 12 uji coba dengan 1.766 pasien di ICU menemukan bahwa vitamin C memperpendek pasien tinggal di ICU sebesar $8 \% .^{25}$ Metaanalisis lain menemukan bahwa vitamin $\mathrm{C}$ mengurangi ventilasi mekanik pada pasien yang membutuhkan ventilasi. Vitamin $\mathrm{C}$ juga menurun pada pasien dalam keadaan kritis..$^{20,25,26}$

Dosis 1-2 gram/hari efektif dalam mencegah infeksi saluran pernapasan atas, karena tidak dapat dicapai melalui sumber makanan saja, suplementasi dapat disarankan bagi mereka yang berisiko lebih tinggi terkena infeksi saluran pernapasan. Namun, dosis di atas 2 gram/hari mungkin tidak menguntungkan untuk individu yang sehat. ${ }^{22}$

Dokter di China melaporkan bahwa 50 pasien COVID-19 dengan non-severe stages yang diberikan terapi vitamin $\mathrm{C}$ dengan dosis tinggi intravena menyebabkan pasien lebih cepat sembuh daripada pasien yang tidak diberikan vitamin $\mathrm{C} .{ }^{27}$ Vitamin $\mathrm{C}$ dengan dosis tinggi intravena dapat mempercepat oksidasi hemoglobin. ${ }^{28}$ Terdapat efek perlindungan dari vitamin C dalam pemberian intravena dosis tinggi selama ARDS yang diinduksi sepsis. Vitamin C memperkuat penghalang epitel alveolar dan secara transkripsi meningkatkan saluran protein yang mengatur pembersihan cairan alveolar. Pemberian vitamin $\mathrm{C}$ intravena dosis tinggi dapat menurunkan secara signifikan mortalitas pada sepsis berat dan ARDS. ${ }^{7}$ Intravena dosis tinggi vitamin C 
terbukti secara klinis aman dan tidak ada efek samping. ${ }^{29}$

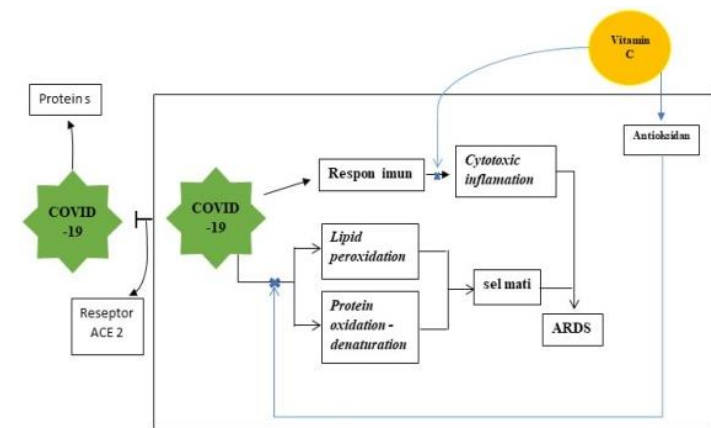

Gambar 1. Mekanisme Vitamin C pada COVID 19

Pengobatan vitamin C dosis tinggi bertindak sebagai prooksidan untuk sel imun, tetapi sebagai antioksidan untuk sel epitel paru. pengobatan vitamin $\mathrm{C}$ dapat melindungi imunitas bawaan melalui penghambatan sekresi laktat. Pemberian vitamin $C$ dosis tinggi sangat bagus pada pasien COVID-19, namun efek samping yang mungkin timbul dalam pengobatan vitamin C dosis tinggi adalah kematian sel osmotik dari sel imun dan menyebabkan peradangan lokal di alveolar. Oleh karena itu, pengobatan glukokortikoid intravena harus ditambahkan untuk mengurangi kemungkinan inflamasi dari pengobatan vitamin $\mathrm{C}$ dosis tinggi. Vitamin C intravena dosis tinggi $50 \mathrm{mg} / \mathrm{kilogram}$ berat badan setiap 6 jam selama 4 hari dengan glucose restriction, lalu hidrokortison $50 \mathrm{mg}$ IV setiap 6 jam selama 7 hari harus diberikan untuk melawan peradangan yang disebabkan oleh terapi. ${ }^{30}$

Tanpa gejala dan gejala ringan diberikan tablet vitamin $\mathrm{C}$ non acidic $500 \mathrm{mg} / 6-8$ jam oral (untuk 14 hari) atau tablet isap vitamin C $500 \mathrm{mg} / 12$ jam oral (selama 30 hari). Sedangakan Gejala sedang dan gejala beratdiberikan vitamin C 200-400 mg/8 jam dalam $100 \mathrm{cc} \mathrm{NaCl} 0,9 \%$ habis dalam 1 jam diberikan secara drips Intravena (IV) selama perawatan. ${ }^{31}$ Pemberian intravena lebih baik daripada oral karena kadar serum yang masuk ke dalam tubuh intravena 25 kali lebih tinggi daripada oral. ${ }^{32}$

\section{KESIMPULAN}

\begin{abstract}
Berdasarkan hasil telaah jurnal ini dapat disimpulkan bahwa pengunaan vitamin $\mathrm{C}$ dalam terapi pasien COVID-19 sangat membantu dalam peroses penyembuhan. Vitamin C mempunyai efek baik, salah satunya dapat meningkatkan respons imun dalam tubuh pasien. Vitamin $C$ juga dapat melindungi sel tubuh dan mengurangi kerusakan akibat infeksi. Keadaan pasien yang diberikan vitamin C lebih baik daripada pasien yang tidak diberikan.
\end{abstract}

\section{DAFTAR PUSTAKA}

1. Kementrian kesehatan Republik Indonesia. Pedoman Pencegahan dan Pengendalian COVID-19. Pedoman kesiapan menghadapi COVID-19. 2020;0115.

2. Bruce Aylward (WHO); Wannian Liang (PRC). Report of the WHO-China Joint Mission on Coronavirus Disease 2019 (COVID-19). WHO-China Jt Mission Coronavirus Dis 2019 [Internet]. 2020;1(February):40. Available from: https://www.who.int/docs/defaultsource/coronaviruse/who-chinajoint-mission-on-covid-19-finalreport.pdf

3. Duan G. Virology, Epidemiology, Pathogenesis, and Control of COVID-19. 
www.mdpi.com/journal/viruses. 2020;1-17.

4. Ahn DG, Shin HJ, Kim MH, Lee $\mathrm{S}$, Kim HS, Myoung J, et al. Current status of epidemiology, diagnosis, therapeutics, and vaccines for novel coronavirus disease 2019 (COVID-19). J Microbiol Biotechnol. 2020;30(3):313-24.

5. Carr AC. A new clinical trial to test high-dose vitamin $C$ in patients with COVID-19. Crit Care. 2020;24(1):1-2.

6. Liugan $M$, Carr AC. Vitamin C and neutrophil function: Findings from randomized controlled trials. Nutrients. 2019;11(9):116.

7. Kakodkar P, Kaka N, Baig M. A Comprehensive Literature Review on the Clinical Presentation, and Management of the Pandemic Coronavirus Disease 2019 (COVID-19). Cureus. 2020;2019(4).

8. Kannan S, Shaik Syed Ali P, Sheeza A, Hemalatha K. COVID19 (Novel Coronavirus 2019) recent trends. Eur Rev Med Pharmacol Sci. 2020;24(4):2006-11.

9. Susilo A, Rumende CM, Pitoyo CW, Santoso WD, Yulianti $M$, Sinto R, et al. Coronavirus Disease 2019: Tinjauan Literatur Terkini Coronavirus Disease 2019: Review of Current Literatures. J Penyakit Dalam Indones. 2020;7(1):45-67.

10. Atri D, Siddiqi HK, Lang JP, Nauffal V, Morrow DA, Bohula EA. COVID-19 for the Cardiologist: Basic Virology, Epidemiology, Cardiac Manifestations, and Potential
Therapeutic Strategies. JACC Basic to Transl Sci. 2020;5(5):518-36.

11. Shi $Y$, Wang $Y$, Shao $C$, Huang J, Gan J, Huang X, et al. COVID19 infection: the perspectives on immune responses. Cell Death Differ [Internet]. 2020;27(5):1451-4. Available from:

http://dx.doi.org/10.1038/s41418020-0530-3

12. Burhan E, Dwi Susanto A, Nasution SA, Ginanjar E, Wicaksono Pitoyo C, Susilo A, et al. PROTOKOL TATALAKSANA COVID-19 TIM PENYUSUN Perhimpunan Dokter Paru Indonesia (PDPI) Perhimpunan Dokter Spesialis Kardiovaskular Indonesia (PERKI) Perhimpunan Dokter Spesialis Penyakit Dalam Indonesia (PAPDI) Perhimpunan Dokter Anestesiologi dan Terapi Int. 2020

13. Cheng RZ. Can early and high intravenous dose of vitamin C prevent and treat coronavirus disease 2019 (COVID-19)? 2020;(January).

14. Carr AC, Maggini S. Vitamin C and immune function. Nutrients. 2017;9(11):1-25.

15. Tjay, Tan H., and Rahardja, Kirana. (2010). Obat-Obat Penting Kasiat, Pengunaan dan Efek-Efek Sampingnya Edisi Ke Enam. Jakarta : PT Gramedia.

16. Anderson $\mathrm{N}$, Fergus $\mathrm{RR}, \mathrm{Nm} \mathrm{C}$. Vitamin C: A ConcentrationFunction Approach Yields Pharmacology and Therapeutic Discoveries. Adv Nutr. 2011;2(Xii):78-88.

17. Lykkesfeldt J, Michels AJ. Vitamin C. Advances in Nutrition. 
Am Soc Nutr. 2014;5(1):16-8.

17. Erol A. High-dose intravenous vitamin C treatment for COVID19. Osflo/Preprints [Internet]. 2020;19(February). Available from:

https://osf.io/p7ex8/?fbclid=IwAR 2b67345SBs9r2QfJ23xH_0GEM 771Qwww6EPpOSTSpQ7_x2BU u7-5CZEHo

18. Mandl J, Szarka A, Bánhegyi G. Vitamin C: Update on physiology and pharmacology. $\mathrm{Br} \mathrm{J}$ Pharmacol. 2009;157(7):1097110.

19. Kementerian Komunikasi dan Informatika Republik Indonesia (Kominfo RI). 2020.

20. Gunawan, Sulistia G., Setiabudy, R., Nafrialdi, and Instiaty. (2016). Farmakologi dan Terapi Edisi 61. Jakarta : Badan Penerbit FKUI

21. Boretti A, Banik BK. Intravenous vitamin $\mathrm{C}$ for reduction of cytokines storm in acute respiratory distress syndrome. Lancet. 2020;395(April):1315.

22. Iddir M, Brito A, Dingeo G, Del Campo SSF, Samouda $H$, La Frano MR, et al. Strengthening the immune system and reducing inflammation and oxidative stress through diet and nutrition: Considerations during the covid19 crisis. Nutrients. 2020;12(6):1-43.

23. Zabetakis I, Lordan R, Norton C, Tsoupras A. Covid-19: The inflammation link and the role of nutrition in potential mitigation. Nutrients. 2020;12(5):1-28.

24. Hemilä H. Vitamin $C$ and SARS coronavirus [6]. J Antimicrob Chemother. 2003;52(6):1049_ 50.

25. Liu F, Zhu Y, Zhang J, Li Y,
Peng Z. Intravenous high-dose vitamin $C$ for the treatment of severe COVID-19: study protocol for a multicentre randomised controlled trial. BMJ Open [Internet]. 2020;10(7):e039519. Available from: http://www.ncbi.nlm.nih.gov/pub $\mathrm{med} / 32641343$

26. Hemilä H, Chalker E. Reply: Vitamin $\mathrm{C}$ as a Possible Therapy for COVID-19. Infect Chemother [Internet]. 2020;52(2):1-2. Available from: http://www.ncbi.nlm.nih.gov/pub $\mathrm{med} / 32468742$

27. Simonson W. Vitamin C and coronavirus William. 2020;(January).

28. Cheng RZ, Kogan M, Davis D. Ascorbate as Prophylaxis and Therapy for COVID-19-Update From Shanghai and U.S. Medical Institutions. Glob Adv Heal Med. 2020;9:216495612093476

29. Lehene $M$, Fischer-Fodor $E$, Scurtu F, Hădade N, Gal E, Mot $A C$, et al. Excess ascorbate is a chemical stress agent against proteins and cells. Pharmaceuticals. 2020;13(6):110.

30. Kashiouris MG, L'heureux $M$, Cable CA, Fisher BJ, Leichtle SW, Fowler AA. The emerging role of vitamin $C$ as a treatment for sepsis. Nutrients. 2020;12(2):1-16.

31. Adams, K. K., Baker, W. L., and Sobieraj, D. M. (2020). Myth Busters: Dietary Supplements and COVID-19. Annals of Pharmacotherapy. 